\title{
ANTILLEAN ASCALAPHIDAE
}

\author{
By Nathan Banks \\ Museum of Comparative Zoology, Cambridge, Moss.
}

Recently Dr. G. N. Wolcott of Puerto Rico sent me a pair of a small Ascalaphid taken in the southwestern part of the island. This has included me to go over the material in the Museum collection, to straighten out certain points in Van der Weele's Revision and in Prof. R. C. Smith's paper on the Haitian species. We have here the types of Burmeister's senex and of Hagen's avunculus.

Burmeister had two specimens, one from Cuba, one from Savannah, Georgia; these are the same species, and I find no differences between Cuban and United States material but with greater differences between various specimens in the United States. Thus Van der Weele's subspecies, hageni, becomes a synonym of senex.

Van der Weele, having seen a specimen in the Berlin Museum labeled "avunculus", surmised that it might be a Hagen type, and said the antennae were no longer than usual in senex, and that Hagen had made a mistake, and put avunculus as a synonym of senex. The two types of avunculus are here, both males, and with the antennae over thirty millimeters long, so distinct from senex. Prof. Smith listed from Haiti several species, which to me are only specimens of sancti-domingi in varying conditions. But one of them is so different I shall describe it as new.

Of the species macleayana, that Guilding described from St. Vincent, I have seen no specimens, and the photograph shows little, if anything, to separate it from sancti-luciae Weele.

The species in the collection can be tabulated as follows:

1. Hair on lower face dark; stigma never dark; large species_._._._..... 2

Hair on lower face white or almost so

2. In hind wing behind the bend of the first anal the wing is so swollen that the network of cross veins extends past the bend toward the base of wing; four cross veins before radial sector in fore wing---villosus (ampla)

In hind wing the network is interrupted behind the bend of the first anal, the wing being more narrow; three cross-veins before radial sector in fore wings walkeri

3. Antennae of male over 30 millimeters long, much longer than wings; femora as well as tibia very pale avunculus

Antennae of male not 30 millimeters long

4. Stigma in both wings plainly dark (except in teneral specimens); femora rather evenly dark; hair on front of mesonotum normally dark- 
Stigma in both wings very pale or yellow; small species_

5. Mid and hind femora pale, but with dark apical band; white hair on front of mesonotum; much white hair in tuft at base of antennae; stigma yellow smithi

Hair on mesonotum plainly dark, mid and hind femora more evenly dark-- 6

6. Male with a dark spot by stıgma of fore wing, female with spot in hind wing opposita

Male without dark spot in fore wing; vertex a little more narrow_.._-_banksi

7. In fore wings the tip slightly more acute; stigma usually covering four

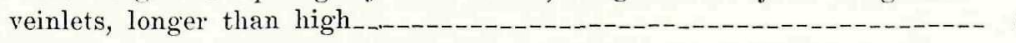

In fore wings the tip rounded; stigma shorter, usually higrer than long - _._.

8. From Cuba and Bahamas; venation of apical part of wing denser, between the third and fourth branches of the radial sector nine to twelve or or more cells senex

From St. Lucia; venation less dense, between the third and fourth branches of the radial sector eight or less cells sancti-lucia

\section{Clulodes villosus Pal. de Beauv.}

The $I^{*}$. ampla MeLach is considered a synonym of this by Van der Weele, and doubtless correctly, as there is probably not another species so large from San Domingo. The Museum has ten specimens from Samana Bay. Its large size and tinted wings readily separate it from all other except $U$. walkeri.

\section{Ululodes ualkeri Weele}

Separated from $\mathcal{C}$. villosus by the narrower wings, especially the hind pair, and darker hair on head. In the collection is one specimen from Poey, wholly pale-winged, and a very dark-winged specimen from the coast below Pico Turquino, 26 to 30 June (Darlington). The tips of hind wings are almost black. It was described from Jamaica.

\section{Ululodes senex Burm.}

The two types (both females) are here; I can see no difference between them that is not found in greater degree in U. S. and Cuban specimens. It is common in Central and Western Cuba. Both male and female sometimes have a dark spot near stigma in hind wing; in some specimens the whole wing is suffused with yellowish brown. In two specimens (Hope, Arkansas and Dallas, Texas) there are four cross-veins before radial sector in the front wing of one side; in one (San Antonio, Texas) there are four in both front wings and tw o in each hind wing. The hair of the antennal tuft is white in front. 
Ululodes avunculus Hag.

The two types (both males) are here; the antennae are over $30 \mathrm{~mm}$. long, much longer than wings; both are from Poey, no definite locality; there is also another Poey male, collected later, and in 1936 Darlington took a male on the south side of Pico Turquino, Oriente, Cuba, 11 June, at 3 to 5,000 feet. I am not sure of the female; there is a female bearing the same number as Poey's third specimen; it is very similar to senex. The species is probably confined to Eastern Cuba.

\section{Ululodes sancti-domingi Weele}

This species is extremely close to $U$. senex, and shows the same color variations, sometimes a dark cloud in apex of hind wing, sometimes the whole wing tinted with yellowish brown. About the only character to distinguish it is the shorter stigma; the tip of wings is more rounded than in senex, but the difference is slight.

What Prof. R. C. Smith listed as $U$. villosus and as $U$ venezolensis are this species; while the form called $U$ subvertens is different and I described it as new-U. smithi.

\section{Ululodes sancti-luciae Weele}

Of this I have but one specimen from St. Lucia. It was described from one male from St. Lucia; had it been from Cuba I think it would be put with $U$. senex: the venation is less dense than in senex but not strikingly so.

\section{Ululodes smithi sp. nov.}

Face mostly dark; hair on lower part white, that at base of antennae largely white, but dark behind; hair on pronotum white, on front of mesonotum also white, above on mesonotum pale gray. Abdomen ( + ) pale, with many black lines on sides, and above on several segments a median dark line, and on each side the elongate triangular mark as usual, with a small spot before it; apical segment largely pale, a median black stripe, and on each side a dark spot on the hind margin; legs pale, but mid and hind femora darkened toward tip, and the tibia within dark, tarsus mostly dark.

Wings hyaline, veins mostly dark, stigma in both wings plainly yellowish; in hind wings of female a dark spot behind stigma. Venation and shape of wing much as in sancti-domingi, apical field rather evenly three-celled; size of sancti-domingi.

From Port-au-Prince, Haiti, 23 Aug. (Smith). Type M.C.Z. No. 23192.

This was treated by Smith (Hayti Neuroptera) as subvertens Walk., a South American species with broader wing's, hardly any 
white in antenal tuft, etc. A male from the same locality has the antennal tuft darker and darker hair on mesonotum, and may belong to this species.

\section{Ululodes opposita sp. nov.}

Face mostly dark, hair on lower part white, the tuft at base on antennae with a little white in front, but mostly dark; antennae pale, with dark apical ring on each joint, tip brown; hair on the pronotum white, that on mesonotum dark gray to brown; pleura with long white hair. Legs pale, the hind femora rather evenly brown; abdomen of male dull black, above with a velvety stripe, broader in front, on each side of segments two, three, and four, between these marks is a median pollinose stripe; hair black, except toward base beneath where it is white; abdomen of female mostly black, above on second, third, and fourth segments mostly pale, with black lines, last segments above mostly black, with a pale median line on apical half.

Wings hyaline; veins mostly dark; stigma, in both wings, pale yellowish, over four veinlets, a little longer than high; tips of wings rounded; venation rather open, apical field with three or four rows of cells; in female a large black spot behind and beyond stigma in hind wings; in male with a more rounded black spot beyond stigma in the fore wings.

Length of fore wing, male, $22 \mathrm{~mm}$., width $6 \mathrm{~mm}$.

Length of fore wing, female, $23 \mathrm{~mm}$., width $6.8 \mathrm{~mm}$.

Length of antenna, male $21 \mathrm{~mm}$., of female $22 \mathrm{~mm}$.

From Cabo Rojo, Puerto Rico, near lighthouse, 4 November. G. N. Woleott and L. P. Martorell. Type M.C.Z. No. 23193:

Unique in the genus in having a black spot in the fore wings.

\section{Ululodes banksi Weele}

Of this Jamaican species we have but one specimen; Kingston, 29 Aug. (Dariington). It is very similar to $U$. opposita, except that the male has no black spot in apex of fore wing. It is a little smaller, and the wing's more narrow. 
PLATE IX

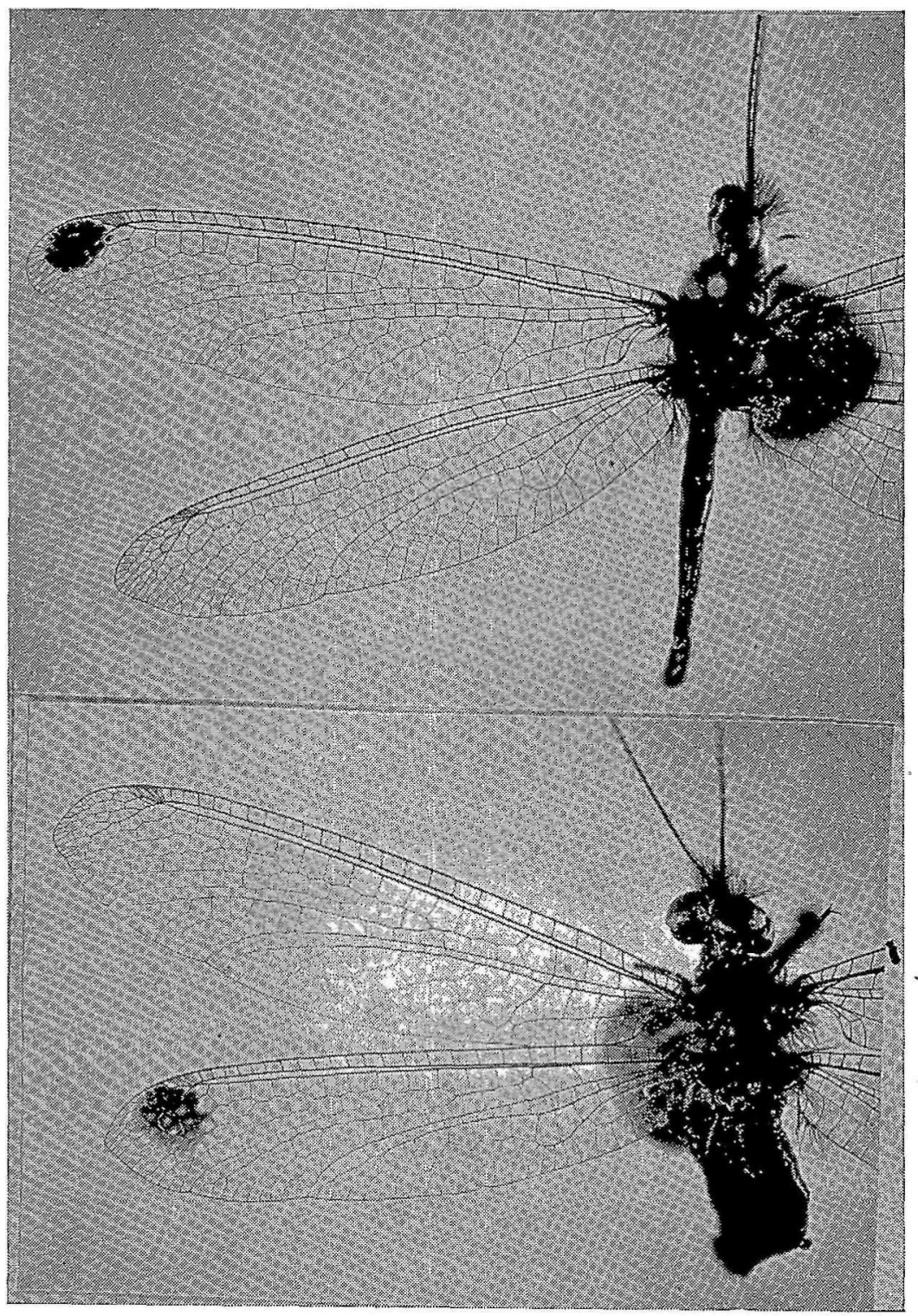

